\title{
ОСОБЛИВОСТІ ФУНКЦІОНУВАННЯ ГЛЮТОНІЧНИХ НАЙМЕНУВАНЬ У ЖІНОЧОМУ РОМАНІ ЛАРИСИ ДЕНИСЕНКО "КАВОВИЙ ПРИСМАК КОРИЦІ"
}

\author{
Ірина Маслясва
}

Криворізький державний педагогічний університет

Kryvyi Rih State Pedagogical University

пр. Гагаріна, 54, Кривий Ріг, 50086, Украӥна

masliaievairyna@gmail.com

Масляєва I. Особливості функціонування глютонічних найменувань у жіночому романі Лариси Денисенко “Кавовий присмак кориці”

У статті досліджено поліаспектне явище глютонії, розкрито зміст поняття “глютонім", окреслено структурно-семантичні й лінгвокультурні особливості глютонічних найменувань, репрезентованих у романі Лариси Денисенко “Кавовий присмак кориці”. Установлено особливості функціонування ядерної та периферійної зони глютонімів, з'ясовано, що однокомпонентні й багатокомпонентні найменування різняться за своїм складом і походженням, мають в основі диференційні мотивувальні ознаки. Визначено та описано основні типи багатокомпонентних номенів, більшість із яких становить двоскладні іменниково-прикметникові словосполученя.

Ключові слова: глютонічний дискурс, глютонім, глютонія, назви страв.

Масляева И. Особенности функционирования глюттонических наименований в женском романе Ларисы Денисенко “Кофейный привкус корицы”

В статье исследуется полиаспектное явление глюттонии, раскрывается содержание понятия “глюттоним”, определяются структурно-семантические и лингвокультурные особенности глюттонических наименований, представленных в романе Ларисы Денисенко “Кофейный привкус корицы”. Акцентируется на особенностях функционирования ядерной и периферийной зоны глюттонимов. Выяснено, что однокомпонентные и многокомпонентные наименования различаются по своему составу и происхождению, имеют в основе дифференциальные мотивирующие признаки. Определяются и описываются основные типы многокомпонентных номенов, большинство из которых составляет двусложные именительно-прилагательные словосочетания.

Ключевые слова: глюттоничний дискурс, глюттоним, глюттония, названия блюд. 
Masliaieva I. Features of the functioning of glutonic names in a female novel by Larisa Denisenko "Cinnamon coffee taste"

The article deals with the process of studying of glutonic names that represent the features of the glutonic discourse which there is an object of interest of scholars not only from the point of view of linguistics and its individual areas, such as: linguoculture, linguistics, linguistic and semiotics, but also cultural studies, sociology and literary studies.

The article investigates the multi-aspect phenomenon of glutonium, reveals the meaning of the concept of "glutonium", outlines the structural-semantic and lingvo-cultural features of the glutonic names represented in the novel by Larisa Denisenko "Cinnamon coffee taste". The peculiarities of the functioning of the nuclear and peripheral zone of glutoniums were established, it was found that onecomponent and multi-component names differ in their composition and origin, and in the basis of differential motivational features. The main types of multicomponent nomines are identified and described, most of which are two-component nounadjective phrases.

The results of the investigation showed that glutoniums are one of the leading and prominent themes of national linguistics, since they represent the socalled "eatable panorama" of artistic Ukrainian literature of the XXI century, whose texts are not yet sufficiently studied from the point of view of glutonic discourse.

Key words: glutonic discourse, glutonium, glutonia, names of dishes.

\section{Постановка проблеми та її зв'язок із важливими} науковими завданнями. Сьогодні студіювання глютонічних найменувань, які ретранслюють особливості глютонічного дискурсу загалом i жіночої глютонічної прози [Masliaieva / Масляєва 2018:86] зокрема, стають об'єктом зацікавлення науковців не лише 3 позиції лінгвістики та окремих іiі царин, якот: лінгвокультурології, лінгвокраїнознавства, лінгвосеміотики і т. ін., але й культурології [Рliuta / Плюта 2017], соціології [Nikolenko / Ніколенко 2015] та літературознавства [Kovpik / Ковпік 2018].

Примітним є те, що глютоніми являють собою одну із провідних i перспективних тем вітчизняного мовознавства, оскільки репрезентують так звану “їстівну панораму” художньої української літератури XXI століття, тексти якої ще не $\epsilon$ достатньо дослідженими з позиції глютонічного дискурсу.

Цілком закономірно, що наше дослідження глютонічних найменувань грунтується на матеріалі прозового мовлення непересічної української письменниці Лариси Денисенко, передовсім на жіночому романі “Кавовий присмак кориці”. 
У мовотворчості авторки особливого значення набуває аспект глютонії, лінгвістична цінність якого увиразнюється за допомогою багатого лексичного рівня, де, своєю чергою, фіксуємо активне вживання найменувань на позначення страв $\mathrm{i}$ напоїв, що, відповідно, й уможливлює поліаспектне (структурносемантичне й лінгвокультурологічне) студіювання кулінарної лексики в художньому стилі.

Аналіз останніх досліджень та публікацій. Науковці, що по-різному підходять до висвітлення тих чи тих проблемних питань глютонічного дискурсу, досить часто, демонструючи теоретичні аспекти дослідження явища, удаються до розгляду його процесу становлення й розвитку, роблять загалом успішні спроби диференціації глютонічних найменувань. Вивчення останніх наукових праць дає змогу констатувати: чимало дослідників обирають за так звану точку відліку аналізованого феномена основоположні праці російського вченого А. Олянича [Olyanich / Олянич 2004]. Низка наукових проблем, пов'язаних iз вивченням феномена глютонії, скерували вектор дослідницьких пошуків у відповідному напрямку й сприяли появі значної кількості праць як монографічного, так і дисертаційного зразків. Щоправда, значна частина наукових розвідок здебільшого демонструє напрацювання зарубіжних учених або дослідження й систематизацію іншомовного матеріалу (Е. Бараташвілі, Е. Гашимова, С. Захарова, А. Земськової, Ф. Косицької, А. Олянича, О. Руфової та ін.).

Окрім того, в умовах сучасного суспільства, коли відбувається процес глобалізації, фіксуємо й активне зацікавлення науковців лінгвокультурним аспектом дослідження феномена глютоніі, де актуальним $є$ зіставне вивчення мовних явищ, що маніфестують специфіку культури різних етноспільнот. Так, скажімо, Л. Срмакова та Г. Тазбулатова здійснили опис лінгвокультурних особливостей глютонічних найменувань на матеріалі англійської мови [Tazbulatova / Тазбулатова 2011], К. Федорова - корейської [Fedorova / Федорова 2017], М. Ундрицова - російської, англійської, французької і грецької [Undritsova / Ундрицова 
2015], Г. Боваєва - калмицької, російської й німецької мов [Bovaeva / Боваева 2012].

Мета й завдання дослідження. Мета статті полягає у з'ясуванні структурно-семантичних i лінгвокультурних особливостей функціонування глютонічної лексики в жіночому романі Лариси Денисенко “Кавовий присмак кориці”.

Виклад основного матеріалу. Сучасні дослідники глютонічного дискурсу здебільшого кваліфікують його як особливий вид масово-інформаційної комунікації, який характеризує всю систему харчового процесу, що складається 3 таких стадій: обробка харчової продукції, підготовка харчової продукції до приготування, процес приготування та споживання їі” [Olyanich / Олянич 2004 : 395]. Однак, науковці донині порізному потрактовують відповідне терміносполучення, оскільки зважають на неусталеність загальноприйнятої назви на позначення глютонічного дискурсу: у багатьох теоретичних працях термін “глютонічний дискурс" вживається як синонім до термінів “кулінарний дискурс", “гастрономічний дискурс", “ресторанний дискурс” [Masliaieva / Масляєва 2018 : 26].

Звідси, відповідно, немає й уніфікації щодо поняття “глютонім": натрапляємо на паралельне вживання термінів “аліментарний код” [Gashimov / Гашимов 2005 : 4], “цибонім” [Ryabova / Рябова 2005 : 5], “густатив” [Kovpik / Ковпік 2018 : 62], які не $є$ однаковими за своїми основоположними властивостями. Попри різнобій у витлумаченні глютонімів більшість дослідників схильна уналежнювати їх до глютонічного дискурсу й класифікувати подібні найменування 3 позиції ядерного членування, 3-поміж якого виокремлюють ядро (власне глютоніми: назви сировини; напівфабрикатів; страв, харчових продуктів i консервів; напоїв) та периферію (глютоніми-локативи й інструментативи, кваліфікатори та емотиви, глютоніми-ідеологеми й естетиви, гендерні знаки, а також директивні знаки-процесиви: дескриптори, регулятиви) [Rudenko / Руденко 2008 : 31].

Аналізуючи глютонічні найменування, наявні в жіночому романі Л. Денисенко “Кавовий присмак кориці”, передовсім 
варто звернути увагу на їхню структурно-семантичну й лінгвокультурну диференціацію.

Упадає в око те, що глютоніми, які ми уналежнюємо до ядерної зони, здебільшого маніфестують назви на позначення харчів, які їдять, та харчів, які п'ють, мають однокомпонентну структуру, як-от: рис, пиріг, банани, бісквіти, горілка, мартіні, абсент, тарталетки і т. ін. Наприклад: Цілими днями вона їла бісквіти ци курила, щуоб не гладшати (1); Банани Аркадій навсправжки любив, обожнював, горілку заїдав тільки ними (1).

Примітним $є$ те, що досить часто однокомпонентні глютоніми увиразнюються супровідними елементами, в основі яких лежать мотивувальні ознаки на кшталт: спільний продукт, форма, якість, смак, вигляд, спосіб приготування й призначення / використання страви чи сировини [Inshakova / Іншакова 2018 : 37]. У такому разі простежується аксіоматична закономірність: трансформуючись, глютонічні найменування набувають ознак багатокомпонентності й утворюють певні типізовані структурні моделі, які можна диференціювати за такими граматичними принципами: 1) назви, що складаються 3 відносного прикметника та іменника; 2) назви, що мають залежний іменник із прийменником з (iз) в орудному відмінку; 3) назви, що мають складну поширену структуру.

Так, назви, що складаються 3 відносного прикметника та іменника, $є$ більш продуктивними й зазвичай маніфестують атрибутивність залежного компонента, здебільшого супроводжувану виявом способу приготування тієї чи тієї страви: зварений рис, тушкована/смажена риба, фарширований перецьь і т. ін. Наприклад: На столі було все наче створене для посту: яйя, рибні салати з майонезом, сир, тушкована та смажена рибка, горілка, мартіні, ром, коньяк, віскі, червоне та біле вино (1).

Подекуди натрапляємо й на поодинокі випадки вживання додаткових атрибутивних елементів на позначення якості продукту: сира риба (Сира риба на звареному рисі, який сформовано на взір пиріжка (1); на позначення смакових властивостей продукту: солоні горішки / огірки (Я рано збагнув, щзо поєднання кефіру, чорносливу та солоних огірків дає такий 
ефект, який був мені конче потрібний (1); на позначення кольору: червоне / біле вино, зелена (ий) цибуля / чай, білий (a) джин / індичка (Вона жувала стеблину зеленої цибулі (1). Іноді фіксуємо глютонічні найменування, де прикметниковий поширювач указує на невід'ємний компонент приготування страви: маковий / горіховий пиріг (1).

Із-поміж назв, що мають залежний іменник із прийменником з (із) в орудному відмінку, натрапляємо на такі, що маніфестують важливість другорядного компонента, адже останній являє собою збірне поняття й указує не тільки на унікальність страви, але й на іï основний інгредієнт або ж начинку: рогалики з висівками, омлети з грибами / кропом / анчоусами, горілка з перцем, кава з корицею і т. ін. Наприклад: Рогалики з висівками, кава у величезних картонних склянках, омлети з грибами, омлети 3 кропом, омлети 3 анчоусами, мед, джем, бекон (1).

Варто зазначити, що авторка досить активно послуговується глютонімами, які мають складну поширену структуру. Звідси, відповідно, фіксуємо найрізноманітніші граматичні кореляції, як-от: кава у величезних картонних склянках, дитяче печиво у вигляді звіряток-монстрів, тонко накраяна шинка з індччки, ніжний шматок сала з часничиною, чорний шоколад із помаранчевими цукатами, рибний салат 3 майонезом і т. ін. Наприклад: Я сконцентрований, бо несу чашки, чай, заварник, молоко для Алекса (він не вживає чаю без молока) та дитяче печиво у вигляді звіряток-монстрів (бачили б ви, яке в цих пекарів вийшло собача...(1); Тоді я вийшов до найближчої крамничі, купив пляшку джину, тонко накраяну шинку 3 індички та фірмовий ніж (1). Багатокомпонентні глютонічні словосполучення здебільшого пов'язані між собою підрядним зв'язком відмінкового прилягання.

Окремо можна акцентувати на поодиноких випадках вживання іменниково-прикметникових глютонічних назв, супровідні елементи яких указують на місце виготовлення продукту, час або приуроченість тієї чи тієї страви до певної події: бочкове пиво, весняний салат, святковий Олів'є. 
Наприклад: Розповідь про родину. Весняний салат. Салат із крабів. Ї̈ перше кохання (1); Гроші в мене є, тому я замовляю собі фарширований перець та бочкове пиво (1). Серед іменниково-прислівникових словосполучень, у яких залежний компонент передає інформацію про особливості приготування страви, властиві певній території [Ostroushko / Остроушко 2017 : 409], фіксуємо лише один компонент, семантичне навантаження якого певною мірою репрезентує й лінгвокультурну особливість української етноспільноти, - котлета по-київськи (1).

Зауважимо: специфічною рисою глютонімів, які ми уналежнюємо до ядерної зони, є те, що в деяких лінгвістичних одиницях закодований певний стереотипно усталений лінгвокультурний елемент. Так, можемо говорити про глютонічні найменування на кшталт: текіла-бум, бехеровка, ром, джин, кока-кола лайт (1) і т. ін. Наприклад: Це так банально звучить - казкова Прага, але вона все одно - казкова. Місто м'якого джазу, натовпів молоді в костелах, галасливих купок німецьких та італійських туристів у шинках $і$ кав'ярнях. Бехеровка та абсент (1); Нове покоління - Мітя - вирішило не відставати, відсалютувавши нам бляшанкою "Коки-коли лайm” (1). Цілком закономірно, що в умовах міжкультурної комунікації загальновідомим стало стереотипне уявлення про країну походження й, так би мовити, країну-споживача відповідних алкогольних напоїв. Глютонім текіла асоціюється 3 Латинською Америкою, ром - із Кубою, бехеровка - із Чехією (можемо бачити з поданого вище контексту), джин - 3 Англією, кока-кола в різних ії варіаціях - із Сполученими Штатами Америки.

Варто, очевидно, наголосити й на тому, що лінгвістичне студіювання не лише ядерної, але й периферійної зони, $є$ невід'ємною частиною комплексного аналізу глютонічної лексики, наявної в аналізованому творі. Хоч у художньому мовленні Л. Денисенко периферійна зона глютонічних найменувань представлена досить побіжно (відсутні глютонімиідеологеми й естетиви, гендерні знаки та регулятиви), проте $є$ потреба більш детально зупинитися на аналізі глютонімівлокативів, інструментативів, кваліфікаторів, емотивів і 
дескрипторів, бо такі номени $є$ яскравими репрезентантами особливостей лінгвокультури тієї чи тієї нації.

До знаків-локативів належать лексеми, які номінують місце походження глютоніма або ж спосіб його приготування, що передбачає наявність певного топонімічного компонента. Так, із-поміж відповідних знаків натрапляємо на ті, що містять у складі прикметниковий поширювач, семантичне навантаження якого вказує на ту чи ту країну, із якої походить страва: китайський суп, американський віскі, франиузький брют, німецькі ковбаски, ризький бальзам, “салат російський”, швейщарський шоколад (1). Наприклад: Змилини неначе стікають у вашу тарілку з китайським супом (зі спеціальними добавками за бажанням клієнта, до рахунку додають доларів 30 (1); Навіщо після ризького бальзаму, горілки з перцем, пива знову пити горілку без перияю? (1). Деякі глютонічні номінації, у структурі яких $€$ певний топонімічний поширювач, іноді увиразнюються супровідними елементами на позначення дороговизни того чи того глютоніма. Пор.: У нас дві пляшки 3 дорогим кримським мускатом (1); Те саме я відчув, коли вперше спробував оті японські, хвалені богемою “суші" (1).

Якщо в наведених вище прикладах походження глютонічних найменувань $є$ достатньо прозорим, то варто апелювати й до лексем, значення топонімічного компоненту яких потребує певних довідкових знань. Серед наявного фактичного матеріалу фіксуємо такі номени: коньяк / коньячок, текіла, шампанське (1), де коньяк - глютонім, який походить від одноіменного міста у Франції; текіла - глютонім, який походить від одноіменного міста в центральній частині мексиканського штату Халіско; шампанське - глютонім, що походить від назви історичної області Шампань у Франції. Натрапляємо на одиничну торговельну марку, семантичне навантаження якої передбачає використання топонімічного компонента - “Токай”, де “Токай” - номен на позначення вина одноіменної торговельної марки, яка була започаткована на теренах Угорщини.

У науковій спільноті, окрім зазначених лексем, до глютонімів-локативів прийнято уналежнювати ще й ті, які 
номінують місце приготування та споживання їжі. Зауважимо: Л. Денисенко досить активно послуговується такими глютонічними назвами: вагон-ресторан, бар, кав'ярня, кафе, ресторан (1) і т. ін. Упадає в око те, що часто відповідні глютоніми в мовотворчості авторки набувають негативного забарвлення i, так би мовити, демонструють самобутній український колорит, як-от: шинок, пивниия, генделик (1). Подекуди можемо навіть із самого контексту почерпнути додаткову інформацію про колорит тієї чи тієї нації: Відтак, $九$ радме визнаю, що мало розуміюся на тому, що роблять франиузи $і$ решта народів, коли їм добре або зле, ніж наполягатиму, мовляв, натовпами вони біжать до шинків, поглинаючи старанно зафіксовані статистикою обсяги вина й пива (1); I пішла до бару. Мені остогидла ия пивниця (1); Але ми, слов'яни, якщо нам сумно, чи якщо нам радісно, це вже я відчув на собі та знаю з досвіду багатьох приятелів, ідемо до будь-якого генделика $і$ трохи напиваємося, або не трохи, але напиваємося, ие вже напевно (1).

Іноді натрапляємо на вживання глютонімів-локативів, атрибутивний поширювач яких указує на іншокультурні кулінарні практики. Наприклад: Якось я його прямо запитала, це було в японському ресторані, де я вкотре змусила його почервоніти (1). Або ж фіксуємо прикметникові компоненти, що репрезентують так звану “богемність” того чи того закладу харчування. Пор.: Уявіть собі, ви перебуваєте в респектабельному ресторані, в центрі величезного міста, вдень, жерете, як остання капіталістична падлюка, суші $і$ все таке інше <...> (1); А я подумав, що ти просто так вештаєшся дорогими ресторанами посеред робочого дня (1).

Окрему групу з-поміж аналізованого фактичного матеріалу становлять знаки-інструментативи - лінгвістичні знаки на позначення назв кухонних предметів, за допомогою яких відбувається процес приготування та споживання їжі. Зважаючи на те, що мовна канва жіночого роману Л. Денисенко насичена глютонічною лексикою, цілком умотивованим $є$ й активне використання авторкою знаків-інструментативів різного складу, як-от: електричний чайник, срібна десертна ложка, 
ножі, рожни, шпиці, ножі, горнятко з білої порцеляни в прості блакитні квіточки, келих, чарка, пляшка, скляний посуд, заварник (1) і т. ін. Доволі цікавою $є$ авторська інтерпретація деяких предметів кухонного вжитку, яку продукує в межах аналізованого тексту персонаж твору. Наприклад: Улюблене слово Міхала “пї̈сяшка”, це 50-грамова чарка, звісно, щуо вона має бути сповнена абсенту. Відповідний глютонімінструментатив указує виключно на українські реалії, ментальний код яких в умовах міжкультурної комунікації, очевидно, зчитується не всіма реципієнтами.

Дібраний фактичний матеріал демонструє надмірне вживання знаків-кваліфікаторів та емотивів - лінгвістичних знаків, що позначають найменування смакових якостей продуктів або страв. Загалом такі глютоніми містять загальні опозиції прислівникового походження на зразок смачно / несмачно, проте знаки-кваліфікатори мають ще й ступінь позитивної чи негативної смакової оцінки. Так, глютонічні назви 3 негативною й позитивною оцінкою представлені здебільшого прикметниками: гіркуватий, паскудний, чудовий, запашний, солодкий, смачний (1). Наприклад: Я так давно не пила цьвого паскудного радянського шампанського, треба випити, воно звалюе з ніг (1); Колись до нашої школи приїжджав гіпнотизер, $і$ мене на все життя вразила та обставина, щуо він змусив мене з'їсти цибулю, запевняючи в тому, що то є запашне яблуко (1); $Я$ й сам тут випадково опинився, привіз мамі смачних грецьких равликів (1) тощо.

Поодиноко натрапляємо на знаки-кваліфікатори, які ілюструють індивідуальні вподобання персонажів: Я обожнюю цеей запах, запах улюбленої батьківської кави (1) або указують на так звану “корисність” страви: Розтягуючи гармошку та губи в усмішиі, виконувати пісні про калинку, малинку, решту корисних ягід-фруктів (1); Знежирений кефір - напевне, дуже смачно. А може, навіть і корисно (1).

На відміну від раніше аналізованих літературно-художніх текстів жіночої прози [Masliaieva / Масляєва 2018], роман Л. Денисенко не містить розгорнутих рецептів приготування тієї чи тієї страви, а відтак - фактичний матеріал засвідчує досить 
побіжне використання знаків-дескрипторів, які $\epsilon$ загальновідомими (адже описують буденні кулінарні реаліі) й дещо, так би мовити, позбавлені оригінальності. Наприклад: Там він про щзось думав, курив, варив чи молов улюблену каву 3 корицею, хоча напевно я не знаю, щуо він там робив (1).

\section{Висновки та перспективи подалыших наукових} розвідок. Студіювання явища глютонії як лінгвокультурного феномена на сучасному етапі розвитку вітчизняної мовознавчої науки поки що немає чітких теоретичних засад, адже глютонія, як і глютонічний дискурс, - відносно нові поняття, які потребують усебічного аналізу. Сьогодні глютонічний дискурс репрезентує жанрове розмаїття, серед якого вирізняються й так звані “фрагменти глютонічного дискурсу”, проілюстровані зразками сучасної української жіночої прози, що маніфестують не тільки художню, але й глютонічну картину світу.

Перспективи подальшого дослідження вбачаємо в поглибленому аналізі елементів глютонічного дискурсу (зокрема - у комплексному вивченні лінгвокультурних та структурно-семантичних особливостей глютонічних найменувань на матеріалі сучасної української художньої літератури).

\section{Література}

1. Боваева Г. М. Лингвокультурная специфика этнических пищевых предпочтений : на материале глюттонических номинаций калмыцко-, русскои немецкоязычных этносов : автореф. дис. ... канд. филол. наук. : 10.02.20. Элиста, 2012. $24 \mathrm{c}$.

2. Гашимов Э. А. Структурно-семантические и прагматические характеристики английского лингвокультурного кода (на материале лексикофразеологического поля “Продукты питания") : автореф. дисс. ... канд. филол. наук : 10.02.04. Самара, 2005. $31 \mathrm{c}$.

3. Іншакова I. О., Стахова К. Ю. Структурно-семантичні особливості лексики на позначення страв українського народу в кулінарних книгах. Філологічні студї : Науковий вісник Криворізького державного педагогічного університету. Кривий Ріг : ФОП Маринченко С. В., 2018. Вип. 17. С. 33-44.

4. Ковпік С. І. Поетика густативів (на матеріалі сучасної української прози) : монографія. Київ : “НВП Інтерсервіс", 2018. 150 с.

5. Масляєва I. В. Назви страв у сучасному художньому мовленні : структурно-семантичний та функціонально-стилістичний аспекти : дис. ... магістер філол. наук : 10.02.01. Кривий Ріг, 2018. 100 с. 
6. Ніколенко В. В. Гастрономічні детермінанти суспільного життя : соціологічний вимір : дис. ... д-ра соціол. наук : 22.00.04. Дніпропетровськ, 2015. $407 \mathrm{c}$.

7. Олянич А. В. Презентационная теория дискурса : монография. Волгоград : Парадигма, 2004. $507 \mathrm{c}$.

8. Остроушко О. А. Структурні типи назв страв у “Практичній кухні". Філологічні студії : Науковий вісник Криворізького державного педагогічного університету. Кривий Ріг : ФОП Маринченко С. В., 2017. Вип. 16. С. 399-412.

9. Плюта О. П. “Гастрономічна культура" $i$ “національна кухня” як поняття гуманітарних досліджень їжі. Young Scientist. 2017. № 7 (47). C. 159-163. URL : molodyvcheny.in.ua/files/journal/2017/7/36.pdf (дата звернення: 11.02.2019).

10. Руденко С. М. Лінгвістичні знаки-кваліфікативи у складі глютонічного дискурсу. Мова і культура : Науковий журнал Київського наиіонального університету імені Тараса Шевченка. Київ, 2008. Вип. 10. Т. Х. (110). C. 30-38.

11. Рябова Л. Русская и чешская цибонимия в лингвокультурологическом аспекте : дисс. ... магистер філол. наук. (славянская филол.). Тарту, 2005. 240 с.

12. Тазбулатова Г. К. Лингвокульторологическое поле "Restaurant food" (на материале англоязычных текстов меню) : дис. ... магистр филол. наук : 6М020500. Павлодар, 2011. 100 с.

13. Ундрицова М. В. Глюттонический дискурс : лингвокультурологические, когнитивно-прагматические и переводческие аспекты (на материале русского, английского, французского и греческого языков) : дис. ... канд. филол. наук : 10.02.20. Москва, 2015. 204 с.

14. Федорова К. М. Лингвокультурная специфика глюттонического дискурса (на примере рецептов корейской и якутской кухни) : автореф. ... магистр филол. наук : 45.04.01. Якутск, 2017. 20 с.

\section{Список використаних джерел}

1. Денисенко Л. В. Кавовий присмак кориці. Київ, 2007. 256 с. URL : https://www.e-reading.club/bookreader.php/1014461/Denisenko_-_Kavoviy_prismak_ korici.html (дата звернення: 11.02.2019).

\section{References}

1. Bovaeva G. M. Lingvokulturnaya spetsifika etnicheskih pischevyih predpochteniy : na materiale glyuttonicheskih nominatsiy kalmyitsko-, russko- i nemetskoyazyichnyih etnosov : avtoref. dis. ... kand. filol. nauk. : 10.02.20. Elista, 2012. $24 \mathrm{~s}$.

2. Gashimov E. A. Strukturno-semanticheskie i pragmaticheskie harakteristiki angliyskogo lingvokulturnogo koda (na materiale leksiko-frazeologicheskogo polya "Produktyi pitaniya") : avtoref. diss. ... kand. filol. nauk : 10.02.04. Samara, 2005. $31 \mathrm{~s}$.

3. Inshakova I. O., Stakhova K. Yu. Strukturno-semantychni osoblyvosti leksyky na poznachennia strav ukrainskoho narodu $\mathrm{v}$ kulinarnykh knyhakh. Filolohichni studii : Naukovyi visnyk Kryvorizkoho derzhavnoho pedahohichnoho universytetu. Kryvyi Rih : FOP Marynchenko S. V., 2018. Vyp. 17. S. 33-44. 
4. Kovpik S. I. Poetyka hustatyviv (na materiali suchasnoi ukrainskoi prozy) : monohrafiia. Kyiv: "NVP Interservis", 2018. $150 \mathrm{~s}$.

5. Masliaieva I. V. Nazvy strav u suchasnomu khudozhnomu movlenni : strukturno-semantychnyi ta funktsionalno-stylistychnyi aspekty : dys. ... mahister filol. nauk : 10.02.01. Kryvyi Rih, 2018. $100 \mathrm{~s}$.

6. Nikolenko V. V. Hastronomichni determinanty suspilnoho zhyttia : sotsiolohichnyi vymir : dys. ... d-ra sotsiol. nauk : 22.00.04. Dnipropetrovsk, 2015. $407 \mathrm{~s}$.

7. Olyanich A. V. Prezentatsionnaya teoriya diskursa : monografiya. Volgograd : Paradigma, 2004. $507 \mathrm{~s}$.

8. Ostroushko O. A. Strukturni typy nazv strav u "Praktychnii kukhni". Filolohichni studii : Naukovyi visnyk Kryvorizkoho derzhavnoho pedahohichnoho universytetu. Kryvyi Rih : FOP Marynchenko S. V., 2017. Vyp. 16. S. 399-412.

9. Pliuta O. P. "Hastronomichna kultura" i "natsionalna kukhnia" yak poniattia humanitarnykh doslidzhen yizhi. Young Scientist. 2017. № 7 (47). S. 159-163. URL : molodyvcheny.in.ua/files/journal/2017/7/36.pdf (data zvernennia: 11.02.2019).

10. Rudenko S. M. Linhvistychni znaky-kvalifikatyvy u skladi hliutonichnoho dyskursu. Mova i kultura: Naukovyi zhurnal Kyivskoho natsionalnoho universytetu imeni Tarasa Shevchenka. Kyiv, 2008. Vyp. 10. T. Kh. (110). S. 30-38.

11. Ryabova L. Russkaya i cheshskaya tsibonimiya $\mathrm{v}$ lingvokulturologicheskom aspekte : diss. ... magister filol. nauk. (slavyanskaya filol.). Tartu, 2005. $240 \mathrm{~s}$.

12. Tazbulatova G. K. Lingvokultorologicheskoe pole "Restaurant food" (na materiale angloyazyichnyih tekstov menyu) : dis. ... magistr filol. nauk : 6M020500. Pavlodar, 2011. $100 \mathrm{~s}$.

13. Undritsova M. V. Glyuttonicheskiy diskurs : lingvokulturologicheskie, kognitivno-pragmaticheskie i perevodcheskie aspektyi (na materiale russkogo, angliyskogo, frantsuzskogo i grecheskogo yazyikov) : dis. ... kand. filol. nauk : 10.02.20. Moskva, 2015. $204 \mathrm{~s}$.

14. Fedorova K. M. Lingvokulturnaya spetsifika glyuttonicheskogo diskursa (na primere retseptov koreyskoy i yakutskoy kuhni) : avtoref. ... magistr filol. nauk : 45.04.01. Yakutsk, 2017. $20 \mathrm{~s}$.

\section{Spysok vykorystanykh dzherel}

1. Denysenko L. V. Kavovyi prysmak korytsi. Kyiv, 2007. 256 s. URL : https://www.e-reading.club/bookreader.php/1014461/Denisenko_-_Kavoviy_prismak_ korici.html (data zvernennia: 11.02.2019).

Стаття надійшла до редакиії 15.02.2019 р. Прийнята до друку 07.05. 2019 р. 